\title{
Sahel Afforestation and Simulated Risks of Heatwaves and Flooding Versus Ecological Revegetation That Combines Planting and Succession
}

\author{
Lorenz Huebner ${ }^{*}$, Ayad M. Fadhil Al-Quraishi², Oliver Branch ${ }^{3}$, Heman A. A. Gaznayee ${ }^{4}$ \\ ${ }^{1}$ Flensburg, Germany \\ ${ }^{2}$ Petroleum and Mining Engineering Department, Faculty of Engineering, Tishk International University, Erbil, Kurdistan Region, \\ Iraq \\ ${ }^{3}$ Institute of Physics and Meteorology, University of Hohenheim, Stuttgart, Germany \\ ${ }^{4}$ Department of Forestry, College of Agricultural Engineering Sciences, Salahaddin University, Erbil, Kurdistan Region, Iraq \\ Email: ${ }^{*}$ L-Huebner@GMX.de
}

How to cite this paper: Huebner, L., Al-Quraishi, A. M. F., Branch, O., \& Gaznayee, H. A. A. (2022). Sahel Afforestation and Simulated Risks of Heatwaves and Flooding Versus Ecological Revegetation That Combines Planting and Succession. Journal of Geoscience and Environment Protection, 10, 94-108.

https://doi.org/10.4236/gep.2022.102007

Received: January 10, 2022

Accepted: February 25, 2022

Published: February 28, 2022

Copyright $\odot 2022$ by author(s) and Scientific Research Publishing Inc. This work is licensed under the Creative Commons Attribution International License (CC BY 4.0).

http://creativecommons.org/licenses/by/4.0/ (c) (i) Open Access

\begin{abstract}
Studies simulating the large-scale afforestation of the African Sahel constantly find warning signals of increased risk of extreme temperatures and heatwaves resulting from changes in albedo and latent heat flow. We review the afforestation measures underlying three simulation studies, together with a restoration model in which compartments are formed by greenbelts to enable succession of savanna vegetation, protected from hot wind and drought. Savanna-like vegetation (around 20\% woody plants) will show bright reflective surface and drying of leaves during dry season rather than constant green color, with very different impact on albedo and temperatures. We derive that the simulated risks of extreme heat and flooding from rain will strongly depend on species, shape and density of the new vegetation. Ecological restoration concepts are expected to mitigate or prevent such restoration related climatic risks. Compact afforestation of the Sahel does not appear to be necessary or feasible. A restoration model based on compartmentalization and the protected succession of diverse, climatically adaptable vegetation could also be used in populated drylands, as a sustainable and temperature balancing solution to desertification.
\end{abstract}

\section{Keywords}

Extreme Heat, Vegetational Compartments, Natural Succession, Dryland Restoration, Savanna Vegetation, Sahel Climate Simulation 


\section{Introduction}

"Great Green Walls" (GGW) are large ecological engineering projects of afforestation in semi-arid or arid desertification areas. The Chinese GGW "ThreeNorth Shelterbelt Program" consists of renaturation areas stretched over 4800 $\mathrm{km}$ as world's largest ecological program (Li et al., 2012). Since 2005, a yet larger GGW is planned in the Sahel south of the Sahara with restoration areas over $7500 \mathrm{~km}$ from coast to coast across Africa (OSS-CENSAD, 2008; O'Connor \& Ford, 2014).

We asked how desertification control could be done in an ecologically and climatically neutral way and how the process of natural succession of vegetation can be used in rather densely inhabited drylands like the Sahel. For the Chinese GGW numerous "lessons learned" were published (Sun et al., 2006; Liu et al., 2008; Cao et al., 2011; Huebner, 2020). A positive effect of the restoration measures on soil, agronomy and climate was reported (Tan, 2016; Zhuang et al., 2017). On the other hand, many hydro-ecological risks were observed when the species of planted trees and shrubs were not adjusted to the local soil and climate conditions, with sometimes poor survival rates. Climatically adaptable solutions are therefore highly needed for the large-scale restoration of drylands.

The following features were shown to be crucial in semi-arid and arid revegetation projects (Cao, 2008; Cao et al., 2011; Jin et al., 2011; Wang et al., 2019): The plants used for revegetation ideally should be native, drought resistant and match with plant societies of comparable ecological and climatic conditions. Trees, if planted too densely may outgrow the local water supply even after many years. Natural succession typically results in diverse and climatically adjustable vegetation. In China this method is used in larger scale restoration since 2006 by closing remote areas over many years to enable vegetation recovery (GerleinSafdi et al., 2020).

Climate warming is expected to increase the frequency and duration of heatwaves (Easterling et al., 2000; Coumou \& Rahmstorf, 2012). We review three studies simulating the afforestation of large semi-arid areas of the Sahel (Diba et al., 2019; Odoulami et al., 2017; Saley et al., 2019). Potential thermal effects resulting from afforestation could add to the weather extremes of global warming and forecasted trend of prolonged heatwaves (Diedhiou et al., 2018). Extreme heat can be hazardous to health: During an extreme heatwave in 2010 in Niger both, the population's morbidity and agricultural production were strongly affected (Rome et al., 2015). Afforestation may also aggravate extreme precipitation and flooding (Diba et al., 2016; Saley et al., 2019) so that decision-makers and politicians were warned to take these risks into account when planning large scale afforestation like the Sahel GGW (Diba et al., 2019). These concerns may contribute to a slow progress of this program in some African countries.

On the other hand, we know that restorations are an important measure to fight the degradation of soil, processes of desertification and the related loss of arable land (UNEP, 2019). The soil degradation is generally caused by a growing 
population, with a risk of getting aggravated by climate warming (Wang et al., 2012; Huang et al., 2016). Climate change contributes to poor sustainability of densely planted (non-native) trees (Anderegg et al., 2018; Yao et al., 2019; Noulèkoun et al., 2018). The percentage of woody cover in African savanna ecosystems typically is 10 to $30 \%$, it is strictly adapted to the mean annual precipitation (MAP) of the region (Sankaran et al., 2005; Veldman et al., 2015). Therefore, sustainable restoration here would mimic native savanna-like vegetation. Based on this criterion we suggested a revegetation model for native vegetation to develop in natural succession within compartments, formed by two planted greenbelts that protect from wind and dryness (Huebner, 2020).

In this review we look into the assumed afforestation measures that some recent Sahel GGW simulation studies are based on, together with the land-use changes (LUC) resulting from the above compartmental revegetation model (Huebner, 2020). We compare the calculated and expected vegetation-atmosphere interactions and the climatic impact. The model combining planting and natural succession is used for comparison against the simulation studies because, besides the Chinese example of natural reforestation in closed land and a second "quasinatural restoration" method (Wang et al., 2019), few concepts involve the process of natural succession in drylands. An example of dryland restoration using shelterbelts will be presented for which the long-term effects on the regional climate have been documented. Finally, we review the FAO dryland assessment of necessary restoration in the Sahel (Mansur, 2016) to understand how the Sahel climate simulations are related to the current plans of the FAO to create the African "Great Green Wall".

\section{Simulation Studies: Sahel Large-Scale Afforestation}

Three recent meteorological studies simulating the large-scale afforestation of semi-arid and arid regions of the Sahel are reviewed. We compare the standards of new vegetation and the afforestation-related LUC assumed by the meteorological research groups, and the reported resulting climatic impact.

\subsection{Afforestation of Sahara-Sahel Interface Region}

Diba et al. (2019) investigated the appearance of heatwaves and thermal extremes, assuming a LUC in the Sahara-Sahel interface region, coast to coast across the continent, over five latitudes $\left(15^{\circ} \mathrm{N}-20^{\circ} \mathrm{N}\right)$. From $16^{\circ} \mathrm{W}$ to $40^{\circ} \mathrm{E}$, this would be 2.6 million square $\mathrm{km}$. Land-use would change from grassland $\left(15^{\circ} \mathrm{N}\right.$ $\left.16^{\circ} \mathrm{N}\right)$, semi-desert $\left(16^{\circ} \mathrm{N}-18^{\circ} \mathrm{N}\right)$ and desert $\left(18^{\circ} \mathrm{N}-20^{\circ} \mathrm{N}\right)$ into a mosaic of forests and fields. The standard version of RegCM4 model was used for simulation.

Large scale afforestation would reduce the frequency of temperature extremes over the reforested and other regions, whereas in eastern central Sahel temperature extremes could increase. A decrease in frequency of warm days in spring and summer and a decrease in warm nights during summer was found, partly due to increase in evapotranspiration and humidity. An alarming increase of 
heatwaves is found for the southern Sahel during summer and autumn. The temperature changes are caused by vegetation mediated changes in latent heat flow. The authors reference a similar simulation study (Diba et al., 2016) that finds afforestation related increased risk of extreme precipitation events with flooding, and policymakers are alerted about adverse effects on socio-economic activities and health.

\subsection{Afforestation of West African Savanna}

Odoulami et al. (2017) compare West African climates from 1970 - 2000 against future climate (2030-2060, IPCC scenario RCP 4.5). They simulate forestation of West African savanna over four latitudes $\left(8^{\circ} \mathrm{N}-12^{\circ} \mathrm{N}\right)$, around $2000 \mathrm{~km}$ from west coast to the east. Replacement of grassland with broad-leafed evergreen trees is assumed, on $440 \mathrm{~km} \times 2000 \mathrm{~km}=0.88$ million square $\mathrm{km}$. The RegCM regional simulation model was used. Duration and frequency of heatwaves under future climate conditions is analysed, without and with forestation measures.

Under RCP 4.5 scenario (without forestation), heatwaves are increased over the entire Savanna region throughout the year. The forestation measures are found to further increase duration and frequency of heatwave events over the Savanna zone, mainly during dry season. The neighboring northern Sahel region and the Guinea coast region in the south would benefit from a decrease in number of heatwaves. The authors highlight meteorological risks that need to be taken into account when planning large scale afforestation as a mitigation for climate change.

\subsection{Afforestation Coast to Coast}

Based on earlier "Green Wall" concepts, Saley et al. (2019) simulate LUC with forestation on 1.76 latitudes along the southern edge of the Sahara, coast to coast, so rather a "wall like" narrow structure $\left(14.08^{\circ} \mathrm{N}-15.84^{\circ} \mathrm{N}\right)$. Grasslands are replaced by deciduous needle-leaf trees. From $16^{\circ} \mathrm{W}$ to $40^{\circ} \mathrm{E}$, the area would be 0.92 million square $\mathrm{km}$. The RegCM4.3 model was used and, as in the two former studies simulation done at a resolution of $50 \mathrm{~km}$.

The work finds increased rainfall events and amounts due to forestation (rainy days $+9 \%$ ) and reduced drought events (dry spells $-4 \%$ ). Maximum temperatures and number of warm days are significantly increased over the reforested GGW area (except during summer) and decreased in neighboring regions, partly due to radiative effects (cloud cover, surface albedo). An important warming signal of increased diurnal temperature range is found over the reforested areas that could contribute to heatwave events. The signal is missing during summer due to increase in rainy days with attenuated temperatures.

\section{Renaturation Concept of Greenbelt Network}

In the following we compare the vegetational situation underlying these simulations with concepts of revegetation of drylands that seem more ecologically sus- 
tainable and feasible. We have suggested a network renaturation concept as an answer to hydro-ecological stress found with large-scale afforestation (Huebner, 2020). The model's expected impact on the local climate will be compared against that calculated for the above compact afforestation measures. Few dryland restoration methods make use of the process of natural succession in combination with planted greenbelts. Native shrubs and trees are planted to form two greenbelts, each 10 to $50 \mathrm{~m}$ wide, in parallel 100 to $300 \mathrm{~m}$ from each other. The distance depends on the expected final height of trees. The inner compartment, around 75\% (up to 90\%) of the module area, is protected from wind and drought (Figure 1). Here, savanna or grassland with or without woody plants can develop in assisted natural succession, in accordance with local MAP. Appropriate soil treatment may expedite this process (Huebner et al.., 2022). Existing plants are kept for their protective and nursing effects (Castro et al., 2002).

The planting of greenbelts can already create a minimum vegetation cover of $20 \%-25 \%$. Successful control of desertification was found at or above similar coverage portions (Gao et al., 2011; Zhuang et al., 2017). The same for soil erosion (Snelder \& Bryan, 1995). Such model of combination of planted protective woody belts and an area of succession between them will need protection over long distances. However, sections of the inner compartment can be used for gardening, orchards, agriculture, parks or playgrounds (Figure 1) so that needs and interests of local communities are considered, creating value and long-term engagement in the maintenance work (Huebner et al., 2022).

\section{Climatic Impact: Compact Afforestation vs. Greenbelt Model}

What are the differences to be expected in how the local climate is affected, either

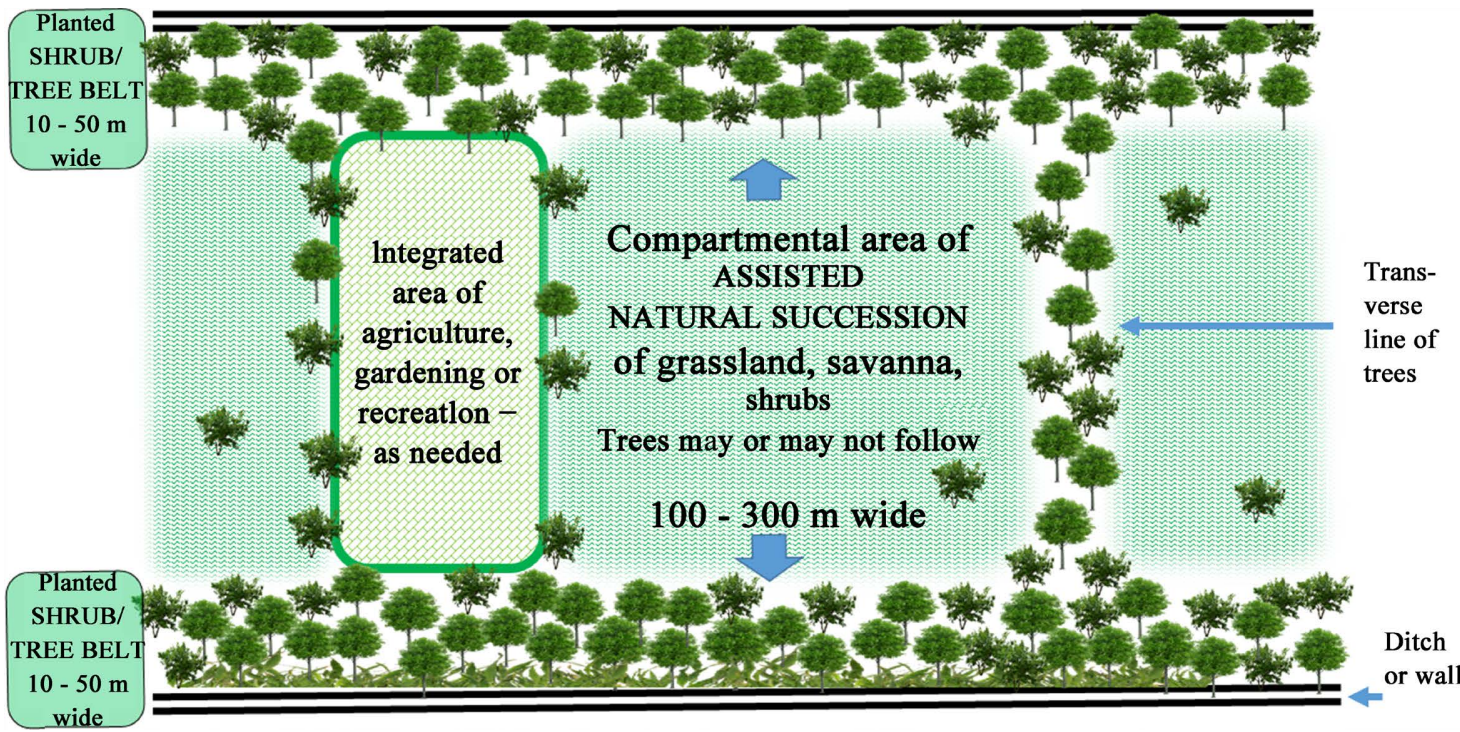

Figure 1. Connective hydrologic module of twin greenbelts, top view. Two flanking shrub/tree belts with area of natural succession between them. Areas of agroforestry or recreation can be integrated.

Modified from (Huebner, 2020). 
by savanna plants that should develop from ecological revegetation measures, or by the vegetation of large-scale planted "forests" underlying the simulations? We present some morphological and adaptational features of savanna plants, and how they may impact various climate factors. Also, a real-life example of regional dryland afforestation is given for which the long-term impact on the regional climate has been documented.

\subsection{Nature of the New Vegetation: Impact on Albedo and Temperature}

The nature of vegetation has an impact on albedo, energy flux and surface temperature. The new vegetation assumed in the three simulation studies was broad-leafed evergreen trees, deciduous needle-leaf trees, or a mix of forests and fields. Broad-leafed evergreen trees seem suitable for humid or sub-humid climates. Needle-leaf species (e.g., Pinus nigra, P. sylvestris, P. halepensis, Cedrus libani) are indeed used successfully in afforestation of semi-arid mountain regions with winter rain, as in Algeria or Turkey (e.g., Boydak \& Caliskan, 2015).

Such vegetation standards imply a dark green vegetational colour throughout the year. A different situation should be expected for natural savanna vegetation of the Sahelian climate zone and for a restoration done here based on natural succession. During around nine months of dry season the leafs of many savanna tree species will dry and show golden colour (e.g., Acacia senegal, A. raddiana, Commiphora africana). Xeromorphic grasses turn into light yellowish colour during this season. The epidermis of many xeromorphic woody plants has grey, white or blue wax cover (cuticula), others have thorns or white "hair" reflecting the sunlight, reduced number of leafs, reduced leaf size, or can turn leafs vertically during noon hours (Bresinsky et al., 2008). The albedo of native savanna plants during dry season therefore will be much higher than that of evergreen broad-leafed or needle-leaf tree forests. Even during rainy season, the low (ca. $25 \%$ ) portion of woody xerophytes of the comparator model will result in far higher reflection compared to the compact cover of simulated forests. Therefore, semiarid and arid grass- and shrubland developing in natural succession will show far lower absorption and warming during the dry and rainy seasons.

\subsection{Precipitation, Risk of Flooding}

The tree cover of savanna is strictly adapted to the regional MAP, typical African savanna have a tree cover between $15 \%$ and 25\% (Veldman et al., 2015), as in the above renaturation model. The compact afforestation assumed in the meteorological studies, however is unlikely to be sustainable in arid or semi-arid climate without additional source of water, e.g. as with a high groundwater table. Growth of densely planted trees can cause hydro-ecological stress, leading to mortality of vegetation (Cao et al., 2011; Jin et al., 2011). In comparison, native grasslands developing in natural succession have low evaporation and water consumption (Milkovic et al., 2019), this component of the module therefore contributes to water storage and stable SMC. 
Like other simulation studies (Becker et al., 2013; Yosef et al., 2018; Branch \& Wulfmeyer, 2019), the simulation of Saley et al. (2019) finds an increase in rainfall events induced by afforestation, which can stabilize vegetation against drought. Together with Diba et al. (2016) they also find a risk of extreme precipitation and flooding, resulting from compact afforestation. The comparator model, if covering e.g., $20 \%$ of an area would limit this risk as there would be evaporation and precipitation from only around 5\% additional woody plants, not $50 \%$ or $100 \%$ as assumed in the simulations.

\subsection{Shape of New Vegetation: Impact on Wind, RH and SMC}

Shape and compartmentalisation of the twin-belt or similar models will increase the region's surface roughness, hundreds of $\mathrm{km}$ of connective modules, created on degraded ground can markedly reduce wind speed across the network and increase RH and SMC in and around the modules. This is precisely the result described for a dense network of tree belts in Northern Jiangsu, China (Zhuang et al., 2017): Shelter-belt plantation along streets, ditches, and land ridges had markedly increased the vegetation from 3\% (1950's) to 36.9\% (2010's). Hot dry desert winds were blocked and regional climate changed from semi-arid to moderately sub-humid above a reported threshold of $16 \%$ tree cover. Days with dry-hot wind decreased from 0 - 20 per year until 1970, to 0 - 10 (1971-1980), and 0 - 3 (2006-2013), paralleled by a $0.63^{\circ}$ decrease (1991-2006) in regional temperatures (Zhuang et al., 2017).

Desert bordering regions with frequent hot winds generally will benefit from such vegetation mediated blocking of wind driven extreme temperatures, in combination with the cooling from evapotranspiration. This is schematically shown for the twin belt model (reviewed in 3), in Figure 2. The module would contribute to increased water storage since compartmentalisation and ditches can direct rainwater into water pools or ground. The plant's evapotranspiration and greenbelt-mediated break of hot desert winds could result in regional climatic changes comparable to those observed in above example of Northern Jiangsu.

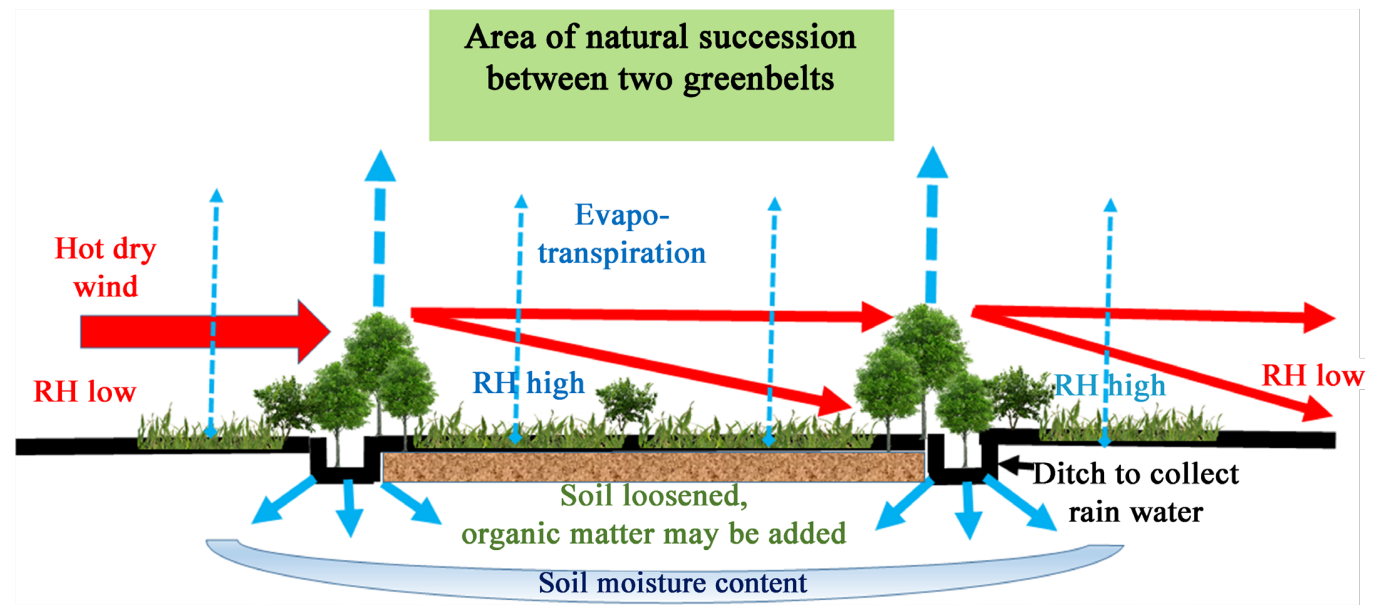

Figure 2. Climatic-hydrological parameters of the twin belt module. 


\section{FAO Assessment of Sahel Restoration Need and Potential}

How are the Sahel climate simulations related to the current plans of the FAO to create the African "Great Green Wall"? The plan was developed on basis of a FAO study of the Sahel desertification status. In 2016 the FAO published a map created from an analysis of 63,000 half hectare sized areas across Sahel drylands (Figure 3, courtesy of FAO). It demonstrates for an African core region of 7.8 million square $\mathrm{km}$ that only a portion, 1.66 million square $\mathrm{km}$ potentially can be targeted for natural regeneration, agroforestry or reforestation of heavily degraded drylands (Mansur, 2016). If realised and finalised per plan in 2030 this LUC would cover $21 \%$ of this huge region: The less transparent green areas on the map represent those of high restoration needs and opportunities. The analysed territory is three times the size assumed in the simulation of Diba et al. (2019) (2.6 million square $\mathrm{km}$ ). The need for restoration was calculated with $21 \%$ of it (Mansur, 2016).

\section{Summary: Climatic Impact of Afforestation Models}

Simulations find an increased risk of heatwave events following the large-scale afforestation of defined regions of the Sahel. In the study of Diba et al. (2019) the

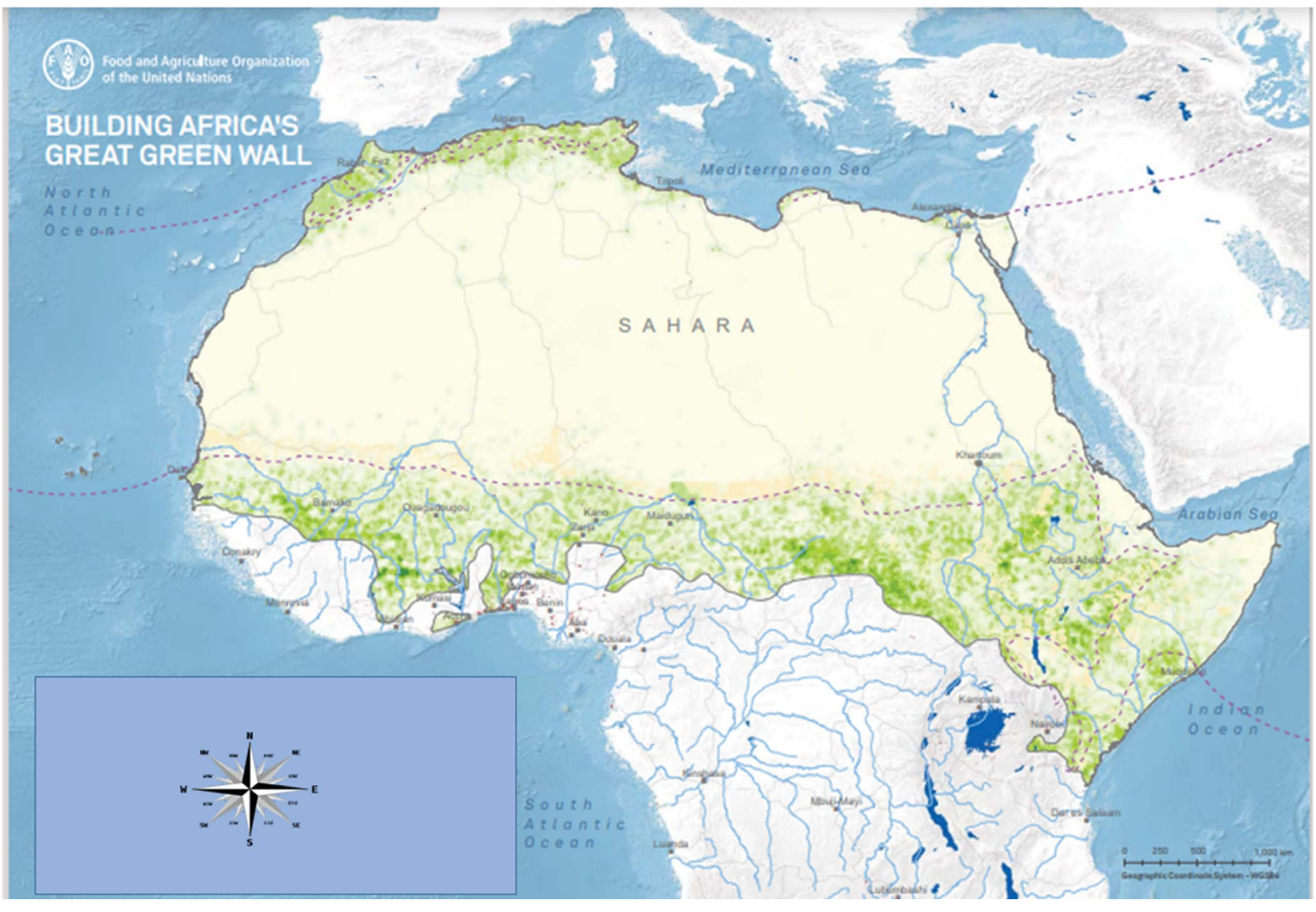

Figure 3. FAO map: Restoration potential of Africa's GGW (Mansur, 2016). Green coloured areas north and south of the Sahara: Less transparent green represents areas of high restoration needs and opportunities, transparent green represents low needs and opportunities of restoration. Permission of the Food and Agriculture Organization of the United Nations. 
days with heatwaves were increased mainly in the south-west Sahel (Senegal, North Guinea, South Mauritania) during summer and decreased over the entire Sahel region during the winter months. The eastern central Sahel could suffer from an increase in extreme thermal values. Also, a moderation of extreme temperatures in GGW neighboring regions was confirmed in all three studies. Some studies find that the reforestation would induce an increase in extreme precipitation events with flooding.

In contrast, we expect less variability and moderation of temperature extremes for a lighter version of renaturation. The twin greenbelt model with low absorptive savanna-like vegetation and low portion of woody plants can be used to create a hydrologic network. Compartmentalisation with woody plant belts can reduce the days with hot-dry wind and increase RH and SMC, as seen in Jiangsu region, China (Zhuang et al., 2017). Table 1 summarises features of the four LUC measures. In our comparator example we assume an overall 20\% LUC from the addition of twin belt modules (5\% planted belts, $15 \%$ natural succession area).

Table 1. Summary of large-scale afforestation models, climatic impact.

\begin{tabular}{|c|c|c|c|c|}
\hline & $\begin{array}{l}\text { Simulation } \\
\text { Diba et al., } 2019 \\
\text { RegCM, } 50 \mathrm{~km} \\
\text { resolution }\end{array}$ & $\begin{array}{l}\text { Simulation } \\
\text { Odoulami et al., } 2017 \\
\text { RegCM, } 40 \mathrm{~km} \\
\text { resolution }\end{array}$ & $\begin{array}{l}\text { Simulation } \\
\text { Saley et al., } 2019 \\
\text { RegCM, } 50 \mathrm{~km} \\
\text { resolution }\end{array}$ & $\begin{array}{l}\text { Hydrologic network of greenbelt } \\
\text { modules, Huebner, } 2020\end{array}$ \\
\hline $\begin{array}{l}\text { Reforestation area } \\
\text { assumption }\end{array}$ & $\begin{array}{l}\text { Sahara-Sahel } \\
\text { Interface Area: } 5 \\
\text { latitudes of Sahel, coast } \\
\text { to coast, ca. } 2.6 \text { million } \\
\mathrm{km}^{2} \text { total area }\end{array}$ & $\begin{array}{l}4 \text { latitudes across } \\
\text { semi-arid Sahel } \\
\text { savanna ca. } 2000 \mathrm{~km} \\
\text { length, ca. } 0.88 \text { million } \\
\mathrm{km}^{2} \text { total area }\end{array}$ & $\begin{array}{l}\text { Northern Sahel Area: } \\
1.76 \text { latitudes coast to } \\
\text { coast, } \\
\text { ca. } 0.92 \text { million } \mathrm{km}^{2} \\
\text { total area }\end{array}$ & $\begin{array}{l}\text { Network of existing vegetation and } \\
\text { new connective modules ( } 25 \% \text { trees, } \\
75 \% \text { grassland). } \\
\text { Example: } \\
\text { Original vegetation: } 10 \% \text {, connective } \\
\text { modules: } 20 \%\end{array}$ \\
\hline $\begin{array}{l}\text { Vegetation } \\
\text { cover } \%\end{array}$ & $100 \%$ fields and forests & $100 \%$ forest & $100 \%$ forest & Example: $30 \%$ total vegetation cover \\
\hline $\begin{array}{l}\text { Composition of } \\
\text { vegetation }\end{array}$ & $100 \%$ crops and trees & $\begin{array}{l}100 \% \text { trees-evergreen } \\
\text { broad leafed }\end{array}$ & $\begin{array}{l}100 \% \text { trees- } \\
\text { deciduous needle leaf }\end{array}$ & $\begin{array}{l}\text { Example: } 10 \% \text { original vegetation, } \\
\text { planting of } 5 \% \text { native shrubs/trees, } \\
15 \% \text { grassland as natural succession } \\
\text { within modules }\end{array}$ \\
\hline $\begin{array}{l}\text { Expected } \\
\text { reduction in } \\
\text { albedo }\end{array}$ & $\begin{array}{l}\text { High: high tree and } \\
\text { crop plant cover }\end{array}$ & $\begin{array}{l}\text { Very high: high tree } \\
\text { cover, evergreen } \\
\text { nature }\end{array}$ & $\begin{array}{l}\text { Very high: high tree } \\
\text { cover, evergreen } \\
\text { nature }\end{array}$ & $\begin{array}{l}\text { Low: low number of woody plants, } \\
\text { native savanna plants reflecting } \\
\text { radiation, light color during nine } \\
\text { months of dry season }\end{array}$ \\
\hline $\begin{array}{l}\text { Extreme } \\
\text { temperature }(\mathrm{T}) \\
\text { days, Risk of } \\
\text { heatwaves }\end{array}$ & $\begin{array}{l}\text { Risk of extreme T in } \\
\text { Central Sahel. } \\
\text { Heatwaves increased } \\
\text { during summer, } \\
\text { decreased in winter }\end{array}$ & $\begin{array}{l}\text { Frequency and } \\
\text { duration of heat wave } \\
\text { events increased over } \\
\text { forested area (Savanna } \\
\text { in W Africa) }\end{array}$ & $\begin{array}{l}\text { T max, warm days, and } \\
\text { risk of heatwaves } \\
\text { increased over } \\
\text { forested area }\end{array}$ & $\begin{array}{l}\text { Additional } 20 \% \text { savanna like } \\
\text { vegetation will add } 5 \% \text { of native } \\
\text { woody plants. More balanced T in } \\
\text { restoration area, fewer days of hot } \\
\text { dry desert wind, local increase in } \mathrm{RH} \\
\text { and SMC }\end{array}$ \\
\hline $\begin{array}{l}\text { Extreme rainfall, } \\
\text { Risk of flooding }\end{array}$ & $\begin{array}{l}\text { Extreme precipitation, } \\
\text { flooding }\end{array}$ & & $\begin{array}{l}\text { Extreme rainfalls, risk } \\
\text { of flooding }\end{array}$ & $\begin{array}{l}\text { Not likely: Savanna with low tree } \\
\text { cover, plants adjusted to dry season; } \\
\text { compartments }\end{array}$ \\
\hline
\end{tabular}




\section{Discussion}

We reviewed three meteorological simulations of large-scale afforestation of the Sahel area and compared the assumed resulting vegetation against that of a restoration model combining the planting of greenbelts and natural succession. This comparison was undertaken in order to address the question of how degraded drylands can be restored in an ecological and climatically neutral way. Policy makers are alerted by the simulated enhanced risks of extreme temperatures and flooding from extreme precipitation resulting from large-scale afforestation, which otherwise can be effective in desertification control. However, the calculated disastrous climatic outcome may be mitigated or prevented by re-introducing vegetation in natural succession, with a savanna-typical proportion of woody plants.

Main differences in the restoration measures were found in the assumed density of LUC: Whilst all simulations are based on a $100 \%$ change in LUC from grassland/ savanna, semi-desert or desert into forests or forests and fields, the example model is based on creation of additional $20 \%$ savanna-like vegetation. Only a certain percentage $(21 \%)$ of the huge Sahel territory was analysed by the FAO to be in need and to offer the possibility of such LUC (Mansur, 2016). If and when realised, such limited restoration should have low climatic consequences, compared to the simulated massive LUC of $50 \%$ or $100 \%$ afforestation as a dense vegetation cover in semi-arid and even arid climate zones. The latter appears to be hydro-ecologically not sustainable, particularly not when evergreen trees of the sub-humid climate would be planted.

Bastin et al. (2019) have evaluated the global forestation potential, just, no one would want to turn natural savanna or dryland ecosystems into dense forest areas. These natural grasslands need to be protected due to their immense biodiversity and groundwater recharge function (University of Witwatersrand, 2019), offering nature's best adapted and sustainable answer to local climate. Aim of the Sahel GGW is to control desertification, to mitigate erosion and sand storms. In practice, renaturation should be based on social (development plans), biophysical and climatic parameters (soil characteristics, groundwater, precipitation) that are mapped before planning. Early stakeholder management is needed to explain how over many years the new vegetation will translate into income and quality of life.

A methodological hurdle of all three simulations could be the resolution and the fact that RegCM standards do not reflect the granularity of degraded areas of "high restoration needs and opportunities" across the Sahel found by the FAO when doing the analysis of half ha sized $(100 \mathrm{~m} \times 50 \mathrm{~m})$ areas (Figure 3; Mansur, 2016). RegCM modelling at higher resolution (e.g., $50 \mathrm{~km}$ ) may be suitable for general applications; it however requires the use of convection parameterization which is known to be weak at reproducing clouds and precipitation appropriately (Prein et al., 2015). High resolution studies down to $2 \mathrm{~km}$ resolution have become feasible at continental, even global scale with benefit of accuracy 
(Schwitalla et al., 2017). Recent studies simulating desert afforestation were able to apply standards based on meteorological data generated in desert forestation projects (Becker et al., 2013; Branch et al., 2014; Yosef et al., 2018). The future of these arid forestation projects will show whether they represent a hydro-ecologically sustainable vegetation standard, with the related questions of irrigation and precipitation.

For natural African savanna we know that, "MAP drives the upper bound on woody cover in arid and semi-arid savannas" (Sankaran et al., 2005). A 15\% $20 \%$ woody plant cover of savannas was found in a wide MAP variability of minimum 250 to $1100 \mathrm{~mm}$, whereas $30 \%$ cover was already correlated with a MAP of minimum $300 \mathrm{~mm}$ (Sankaran et al., 2005). Consequently, sustainable renaturation concepts here should combine low percentage of trees with larger areas of grassland. Connecting the patches of existing vegetation via planted "corridor modules"-such hydrologic network is expected to mitigate extreme temperatures and drought from hot dry storms, as seen in the example of Northern Jiangsu (Zhuang et al., 2017). Woody species of the belts should be native and resilient to future extended drought events. Most suitable species for restoration may not be present locally as yet. A "prestoration" concept was described to identify suitable species and to predict changes in the suitability of habitats in future decades (Butterfield et al., 2017).

Natural succession as the main component of our model takes years of protected development, it results however in numerous ecosystem services, like biodiversity, climatic adaptability and sustainability of vegetation (Liu et al., 2018). In a meta-analysis the drought resilience of grasslands was shown to be high (Matos et al., 2020). Closed constructions with "renaturation compartments" like the twin belt module can enable and ease successional restoration, also in more populated semi-arid and arid regions. As indicated in Figure 1, areas of gardening, agriculture or recreation could be integrated locally in the successional areas (Huebner et al., 2022), thereby adding value for local stakeholders and gaining engagement during the years of maintenance. The latter often is a weak point in large afforestation projects (Holl \& Brancalion, 2020).

\section{Conclusion}

Compact planting of trees ("forests") in drylands bears hydro-ecological risks. These may be mitigated when the restoration aims to establish natural savanna with around 20\% woody plants. There are adaptational-morphological reasons for native savanna species to have low energy absorption, particularly during the around nine months of dry season, with low warming effect. Models involving greenbelts to form compartments with a microclimate of increased RH and SMC should enable and ease the processes of natural succession in arid climate. Further research on restoration models for drylands is suggested that makes use of natural succession to develop diverse native vegetation with higher adaptability to climate change. 
Long-term investigation of the climatic impact of large-scale restoration is needed, like the one done for the $\mathrm{N}$ Jiangsu region, China. As found in this example, desert-like and desert bordering regions with frequent hot winds can benefit from compartmentalisation with shelterbelts that will mitigate the wind driven heat and drought. The feasible restoration of only degraded locations (Sahel: $21 \%$ ) with native, low absorptive vegetation should mitigate or even prevent the risks of heat waves and flooding that have repeatedly been simulated for dense afforestation with subhumid trees at $50 \%$ and $100 \%$ LUC. Further studies using high resolution will help to understand the climatic impact of revegetation that involves successional processes and is based on the feasibility and needs of degraded drylands.

\section{Acknowledgements}

We thank our reviewers for their constructive support, and the FAO for the permission to reproduce the Africa GGW map.

\section{Funding}

This research did not receive any specific grant from funding agencies in the public, commercial, or not-for-profit sectors.

\section{Conflicts of Interest}

The authors declare no conflicts of interest regarding the publication of this paper.

\section{References}

Anderegg, W. R. L., Konings, A. G., Trugman, A. T., Yu, K., Bowling, R. T., Gabbitas, R., Karp, D. S.,Pacala, S., Sperry, J. S., Sulman, B. N., \& Zenes, N. (2018). Hydraulic Diversity of Forests Regulates Ecosystem Resilience during Drought. Nature, 561, 538-541. https://doi.org/10.1038/s41586-018-0539-7

Bastin, J.-F., Finegold, Y., Garcia, C., Mollicone, D., Rezende, M., Routh, D., Zohner, C. M., \& Crowther, T. W. (2019). The Global Tree Restoration Potential. Science, 364, 76-79. https://doi.org/10.1126/science.aax0848

Becker, K., Wulfmeyer, V., Berger, T., Gebel, J., \& Muench, W. (2013). Carbon Farming in Hot, Dry Coastal Areas: An Option for Climate Change Mitigation. Earth System Dynamics, 4, 237-251. https://doi.org/10.5194/esd-4-237-2013

Boydak, M., \& Caliskan, S. (2015). Afforestation in Arid and Semi-Arid Region. Republic of Turkey, Ministry of Forestry and Water Affairs. General Directorate of Combating Desertification and Erosion.

Branch, O., \& Wulfmeyer, V. (2019). Deliberate Enhancement of Rainfall Using Desert Plantations. Proceedings of the National Academy of Sciences of the United States of America, 116, 18841-18847. https://doi.org/10.1073/pnas.1904754116

Branch, O., Warrach-Sagi, K., Wulfmeyer, V., \& Cohen, S. (2014). Simulation of Semi-Arid Biomass Plantations and Irrigation Using the WRF-NOAH Model: A Comparison with Observations from Israel. Hydrology and Earth System Sciences, 18, 1761-1783. https://doi.org/10.5194/hess-18-1761-2014 
Bresinsky, A., Koerner, C., Kadereit, J. W., Neuhaus, G., \& Sonnewald, U. (2008). Lehrbuch der Botanik (36th ed.). Spektrum Akademischer Verlag.

Butterfield, B. J., Copeland, S. M., Munson, S. M., Roybal, C. M., \& Wood, T. E. (2017). Prestoration: Using Species in Restoration That Will Persist Now and into the Future. Restoration Ecology, 25, S155-S163. https://doi.org/10.1111/rec.12381

Cao, S. (2008). Why Large-Scale Afforestation Efforts in China Have Failed to Solve the Desertification Problem. Environmental Science \& Technology, 42, 1826-1831. https://doi.org/10.1021/es0870597

Cao, S., Chen, L., Shankman, D., Wang, C., Wang, X., \& Zhang, H. (2011). Excessive Reliance on Afforestation in China's Arid and Semi-Arid Regions: Lessons in Ecological Restoration. Earth-Science Reviews, 104, 240-245. https://doi.org/10.1016/j.earscirev.2010.11.002

Castro, J., Zamora, R., Hódar, J. A., \& Gómez J. M., (2002). Use of Shrubs as Nurse Plants: A New Technique for Reforestation in Mediterranean Mountains. Restoration Ecology, 10, 297-305. https://doi.org/10.1046/j.1526-100X.2002.01022.x

Coumou, D., \& Rahmstorf, S. (2012). A Decade of Weather Extremes. Nature Climate Change, 2, 491-496. https://doi.org/10.1038/nclimate1452

Diba, I., Camara, M., \& Diedhiou, A. (2019). Impacts of the Sahel-Sahara Interface Reforestation on West African Climate: Intra-Annual Variability and Extreme Temperature Events. Atmospheric and Climate Sciences, 9, 35-61. https://doi.org/10.4236/acs.2019.91003

Diba, I., Camara, M., \& Sarr, A. B. (2016). Impacts of the Sahel-Sahara Interface Reforestation on West African Climate: Intra-Seasonal Variability and Extreme Precipitation Events. Advances in Meteorology, 2016, Article ID: 3262451. https://doi.org/10.1155/2016/3262451

Diedhiou, A., Bichet, A., Wartenburger, R., Seneviratne, S. I., Rowell, D. P., Sylla, M. B. et al. (2018). Changes in Climate Extremes over West and Central Africa at $1.5^{\circ} \mathrm{C}$ and $2{ }^{\circ} \mathrm{C}$ Global Warming. Environmental Research Letters, 13, Article ID: 065020. https://doi.org/10.1088/1748-9326/aac3e5

Easterling, D. R., Meehl, G. A., Parmesan, C., Changnon, S. A., Karl, T. R., \& Mearns, L. O. (2000). Climate Extremes: Observations, Modelling and Impacts. Science, 289, 2068-2074. https://doi.org/10.1126/science.289.5487.2068

Gao, Y., Zhong, B., Yue, H., Wu, B., \& Cao, S. (2011). A Degradation Threshold for Irreversible Loss of Soil Productivity: A Long-Term Case Study in China. Journal of Applied Ecology, 48, 1145-1154. https://doi.org/10.1111/j.1365-2664.2011.02011.x

Gerlein-Safdi, C., Keppel-Aleks, G., Wang, F., Frolking, S., \& Mauzerall, D. L. (2020). Satellite Monitoring of Natural Reforestation Efforts in China's Drylands. One Earth, 2 98-108. https://doi.org/10.1016/j.oneear.2019.12.015

Holl, K. D., \& Brancalion, P. H. S. (2020). Tree Planting is not a Simple Solution. Science, 368, 580-581. https://doi.org/10.1126/science.aba8232

Huang, J. P., Yu, H. P., Guan, X. D., Wang, G. Y., \& Guo, R. X. (2016). Accelerated Dryland Expansion under Climate Change. Nature Climate Change, 6, 166-171. https://doi.org/10.1038/nclimate2837

Huebner, L. (2020). Large Scale Afforestation in Arid and Semi-Arid Climate: Hydrologic-Ecological Lessons Learned and Concept of Modular Hydrologic Connectivity of Vegetation. Journal of Agriculture Food and Development, 6, 10-21. https://doi.org/10.30635/2415-0142.2020.06.02

Huebner, L., Al-Quraishi, A. M. F., Branch, O., \& Gaznayee, H. A. A. (2022). New Ap- 
proaches: Use of Assisted Natural Succession in Revegetation of Inhabited Arid Drylands as Alternative to Large-Scale Afforestation. SN Applied Sciences, 4, 80.

https://doi.org/10.1007/s42452-022-04951-y

Jin, T. T., Fu, B. J., Liu, G. H., \& Wang, Z. (2011). Hydrologic Feasibility of Artificial Forestation in the Semi-Arid Loess Plateau of China. Hydrology and Earth System Sciences, 15, 2519-2530. https://doi.org/10.5194/hess-15-2519-2011

Li, M. M., Liu, A. T., Zou, C. J., Xu, W. D., Shimizu, H., \& Wang, K. Y. (2012). An Overview of the "Three-North" Shelterbelt Project in China. Forestry Studies in China, 14, 70-79. https://doi.org/10.1007/s11632-012-0108-3

Liu, J., Li, S., Ouyang, Z., Tam, C., \& Chen, X. (2008). Ecological and Socioeconomic Effects of China's Policies for Ecosystem Services. Proceedings of the National Academy of Sciences of the United States of America, 105, 9477-9482.

https://doi.org/10.1073/pnas.0706436105

Liu, X., Zhang, W., Cao, J., Yang, B., \& Cai, Y. (2018). Carbon Sequestration of Plantation in Beijing-Tianjin Sand Source Areas. Journal of Mountain Science, 15, 2148-2158. https://doi.org/10.1007/s11629-017-4726-Z

Mansur, E. (2016). 'Great Green Wall' Initiative Offers Unique Opportunity to Combat Climate Change in Africa-UN Agency.

http://www.un.org/sustainabledevelopment/blog/2016/11/great-green-wall

Matos, J. S., Menor, I. O, Rifai, S. W., \& Rosado, B. H. P. (2020). Deciphering the Stability of Grassland Productivity in Response to Rainfall Manipulation Experiments. Global Ecology and Biogeography, 29, 558-572. https://doi.org/10.1111/geb.13039

Milkovic, M., Paruelo, J. M., \& Nosetto, J. D. (2019). Hydrological Impacts of Afforestation in the Semiarid Patagonia: A Modelling Approach. Ecohydrology, 12, Article No. e2113. https://doi.org/10.1002/eco.2113

Noulèkoun, F., Khamzina, A., Naab, J. B., Khasanah, N., van Noordwijk, M., \& Lamers, J. P. A. (2018). Climate Change Sensitivity of Multi-Species Afforestation in Semi-Arid Benin. Sustainability, 10, Article No. 1931. https://doi.org/10.3390/su10061931

O'Connor, D., \& Ford, J. (2014). Increasing the Effectiveness of the "Great Green Wall” as an Adaptation to the Effects of Climate Change and Desertification in the Sahel. Sustainability, 6, 7142-7154. https://doi.org/10.3390/su6107142

Odoulami, R. C., Abiodun, B. J., Ajayi, A. E., Diasso, U. J., \& Saley, M. M. (2017). Potential Impacts of Forestation on Heatwaves over West Africa in the Future. Ecol. Engineering, 102, 546-556. https://doi.org/10.1016/j.ecoleng.2017.02.054

OSS-CENSAD (2008). The Great Green Wall Initiative for the Sahara and the Sahel. Introductory Note Number 3. Sahara and Sahel Observatory (OSS).

Prein, A. F., Langhans, W., Fosser, G., Ferrone, A., Ban, N., Goergen, K., et al. (2015). A Review on Regional Convection-Permitting Climate Modeling: Demonstrations, Prospects, and Challenges. Reviews of Geophysics, 53, 323-361. https://doi.org/10.1002/2014RG000475

Rome, S., Caniaux, G., Ringard, J., Dieppois, B., \& Diedhiou, A. (2015). Identification de Tendances Récentes et Ruptures d'Homogénéité des Températures: Exemple en Afrique de l'Ouest et sur le Golfe de Guinée. Présenté au 28ème colloque international de l'AIC Liège, Belgique, 591-596.

Saley, A., Salack, S., Sanda, I. S., Moussa, M. S., Bonkaney, A. L., Ly, M., \& Fodé, M. (2019). The Possible Role of the Sahel Greenbelt on the Occurrence of Climate Extremes over the West African Sahel. Atmospheric Science Letters, 20, Article No. e927. https://doi.org/10.1002/asl.927 
Sankaran, M., Hanan, N. P., Scholes, R. J., Ratnam, J., Augustine, D. J., et al. (2005). Determinants of Woody Cover in African Savannas. Nature, 438, 846-849. https://doi.org/10.1038/nature04070

Schwitalla, T., Bauer, H.-S., Wulfmeyer, V., \& Warrach-Sagi, K. (2017). Continuous High-Resolution Midlatitude-Belt Simulations for July-August 2013 with WRF. Geoscientific Model Development, 10, 2031-2055. https://doi.org/10.5194/gmd-10-2031-2017

Snelder, D. J., \& Bryan, R. B. (1995). The Use of Rainfall Simulation Tests to Assess the Influence of Vegetation Density on Soil Loss on Degraded Rangelands in the Baringo District, Kenya. CATENA, 25, 105-116. https://doi.org/10.1016/0341-8162(95)00003-B

Sun, G., Zhou, G., Zhang, Z., Wei, X., McNulty, S. G., \& Vose, J. M. (2006). Potential Water Yield Reduction due to Forestation across China. Journal of Hydrology, 328, 548-558. https://doi.org/10.1016/j.jhydrol.2005.12.013

Tan, M. (2016). Exploring the Relationship between Vegetation and Dust-Storm Intensity (DSI) in China. Journal of Geographical Sciences, 26, 387-396. https://doi.org/10.1007/s11442-016-1275-2

UNEP (United Nations Environment Programme) (2019). New UN Decade on Ecosystem Restoration Offers Unparalleled Opportunity for Job Creation, Food Security and Addressing Climate Change. Press Release.

https://www.unenvironment.org/news-and-stories/press-release/new-un-decade-ecosy stem-restoration-offers-unparalleled-opportunity

University of the Witwatersrand (2019, October 21). Large-Scale Afforestation of African Savannas Will Destroy Valuable Ecosystems: African Scientists Speak out about Global Plans to Plant Trees on their Continent in Order to Fight Climate Change. ScienceDaily. http://www.sciencedaily.com/releases/2019/10/191021135029.htm

Veldman, J. W., Overbeck, G. E., Negreiros, D., Mahy, G., Le Stradic, S. et al. (2015). Tyranny of Trees in Grassy Biomes. Science, 347, 484-485. https://doi.org/10.1126/science.347.6221.484-c

Wang, F., Pan, X., Gerlein-Safdi, C., Cao, X., Wang, S., Gu, L., Wang, D., \& Lu, Q. (2019). Vegetation Restoration in Northern China: A Contrasted Picture. Land Degradation \& Development, 351, 120-128.

Wang, L., d'Odorico, P., Evans, J., Eldridge, D., McCabe, M., Caylor, K., \& King, E. (2012). Dryland Ecohydrology and Climate Change: Critical Issues and Technical Advances. Hydrology and Earth System Sciences, 16, 2585-2603. https://doi.org/10.5194/hess-16-2585-2012

Yao, Y., Xie, X., Meng, S., Zhu, B., Zhang, K., \& Wang, Y. (2019). Extended Dependence of the Hydrological Regime on the Land Cover Change in the Three-North Region of China: An Evaluation under Future Climate Conditions. Remote Sensing, 11, Article No. 81. https://doi.org/10.3390/rs11010081

Yosef, G., Walko, R., Avisar, R., Tatarinov, F., Rotenberg, E., \& Yakir, D. (2018) Large-Scale Semi-Arid Afforestation can Enhance Precipitation and Carbon Sequestration Potential. Scientific Reports, 8, Article No. 996.

https://doi.org/10.1038/s41598-018-19265-6

Zhuang, J.-Y., Zhang, J.-C., Yang, Y., Zhang, B., \& Li, J. (2017). Effect of Forest Shelter-Belt as a Regional Climate Improver along the Old Course of the Yellow River, China. Agroforestry Systems, 91, 393-401. https://doi.org/10.1007/s10457-016-9928-9 